\title{
PROTEIN DARI BIOTA LAUT DAN POTENSINYA DALAM INDUSTRI YANG MENGGUNAKAN TEKNOLOGI NANO-SILIKA
}

\author{
Ekowati Chasanah*)
}

\begin{abstract}
ABSTRAK
Peran protein dalam proses pembentukan biosilika yang terjadi di dalam tubuh beberapa biota laut telah menginspirasi peneliti untuk mempelajari dan meniru teknologi tersebut untuk aplikasi industri. Dengan proses biologi biasa, protein dari spikula spons dan dinding sel diatom dapat berfungsi menjadi cetakan dan mendirect proses biosilika berskala nano. Isolasi dan identifikasi protein tersebut, yang dilanjutkan dengan uji coba proses biosilika secara in vitro, memperlihatkan potensi protein tersebut sebagai biokatalis/agen biologi dalam sintesis silika. Sintesis silika secara kimia, seperti dalam produksi bahan resin, katalis, dll, selama ini dikenal merupakan proses yang tidak ramah lingkungan dan boros energi (diperlukan suhu, $\mathrm{pH}$ dan tekanan tinggi). Karena itu, eksplorasi dan riset lebih lanjut mengenai protein ini dirasa sangat penting mengingat bahan dasar silika, termasuk didalamnya teknologi nano, telah dipergunakan dalam berbagai bidang industri termasuk diantaranya industri pangan, elektronika, otomotif, dan lain-lain. Perkembangan riset tentang protein ini, baik yang telah dilakukan oleh peneliti luar negeri maupun yang dilakukan di Indonesia, serta aplikasi teknologi nano-silika akan disampaikan pada makalah ini.
\end{abstract}

KATA KUNCI: biosilika, biota laut, protein

\section{PENDAHULUAN}

Pembentukan material inorganik dibawah kontrol organisma atau biomineralisasi merupakan fenomena umum di alam. Silika merupakan biomineral nomor dua paling banyak di alam dan hanya kalah oleh biogenik $\mathrm{CaCO}_{3}$. Biomineralisasi silika di alam didominasi oleh biota akuatik sederhana termasuk diantaranya oleh organisme bersel tunggal (Diatomae, Radiolaria dan Synurophyta) dan organisma multiselular (spons) (Sumper \& Kroger, 2004). Biota akuatik laut tersebut telah dikenal memiliki kemampuan mengasimilasi materi inorganik seperti silikon dari lingkungan perairan dan membentuk polimer silika dengan berbagai disain unik untuk memperkuat sel dalam tubuhnya ataupun sebagai bagian dari struktur tubuhnya. Kemampuan alami biota ini telah menarik peneliti dan pemerhati industri silika terutama di bidang teknologi nano, seiring dengan perkembangan riset bidang biomimetics, yaitu riset mengenai teknologi pembentukan material dengan sistem biologi atau biomolekul. Selama ini, pembuatan peralatan berskala nano dan berstruktur mikro seperti transistor untuk microchip merupakan pekerjaan yang mahal dan demanding process. Proses sintesis silika yang selama ini dilakukan di industri memerlukan kondisi proses yang boros energi dan tidak ramah lingkungan seperti suhu, $\mathrm{pH}$ dan tekanan tinggi serta menggunakan surfaktan yang dapat mencemari lingkungan. Karena itu, studi biosilika, pembentukan polimer silika pada makhluk hidup, menjadi menarik dan sangat intensif dipelajari untuk mengatasi pada proses sintesis silika untuk industri, terutama yang berskala nano.

Review ini akan mengulas perkembangan terakhir riset biosilika pada diatom dan spons, potensi pengembangan dalam industri serta hasil riset di Indonesia.

\section{Diatom dan Pembentukan Biosilika}

Diatom adalah mikroalga yang dapat ditemukan pada lingkungan akuatik, dan pertama dikenal sejak lebih dari 180 juta tahun yang lalu. Menurut ahli biologi molekuler tanaman Chris Bowler, berdasar studi filogenetik molekuler dan morfologi, diatom diduga berasal dari eukariot yang diserang oleh eukariot fotosintetik seperti alga merah (Bradbury, 2004).

Diatom merupakan alga bersel tunggal dengan ukuran mikro (1-500 mm) dengan dinding sel (frustul) kaku yang berisi silika. Mikroorganisma bersel tunggal ini membentuk struktur dinding sel dengan pola unik yang berukuran dari nano sampai mikrometer yang disebut juga biosilica nanopatterns, yang sangat spesifik untuk tiap spesies. Karena itu, diduga proses biomineralisasi pada diatom tersebut dikontrol secara genetik, dengan perkiraan jumlah spesies lebih dari 100.000 jenis, sehingga pola nano yang unik untuk spesies-spesies tersebut menginspirasi proses pembentukan silika secara biologis (biosilifikasi) pada diatom untuk pengembangan teknologi nano. Berdasar kesimetrisan dinding sel, maka diatom

\footnotetext{
*) Peneliti pada Balai Besar Riset Pengolahan Produk dan Bioteknologi Kelautan dan Perikanan
} 
dibedakan dalam 2 grup besar yaitu pennate dan centric diatom. Untuk keperluan struktur nano, maka tipe centric, yaitu diatom yang memiliki kesimetrisan secara radial yang sangat berpotensi (Parkinson \& Gordon, 1999).

Biosilika diatom terutama terdiri dari silika (amorphous hydrated $\mathrm{SiO}_{2}$ ) dengan sebagian kecil makromolekul organik yang sejak lama diduga ikut berperan dalam mengontrol pembentukan silika dengan pola nanonya. Sintesis silika pada diatom terjadi di dalam silica deposition vesicle (SDV) yang terdapat pada organ intra sel yang dikelilingi oleh membran silicalema. Pembentukan struktur tiga dimensi gel silika di dalam SDV tersebut dipicu oleh $\mathrm{pH}$ rendah. Prekursor pembentukan biosilika dalam SDV sampai dengan saat ini masih terus dipelajari, tetapi keberadaan asam monosilikat di lingkungan perairan, biasanya dalam kisaran $1-100 \mu \mathrm{M}$, secara jelas merupakan sumber utama pembentukan silika. Asam monosilikat ditransportasikan ke dalam sel diatom melalui protein transporter yang berfungsi jika ada $\mathrm{Na}^{+}$(disebut SIT), tetapi mekanisme penyimpanan asam silikat yang bersifat larut tersebut dan model tranportasinya ke dalam SDV belum diketahui.

Dari diatom Cylindrotheca fusiformis, 3 famili protein dinding sel telah berhasil diisolasi dan dikarakterisasi, yaitu frustulins $\left(\mathrm{Ca}^{+}\right.$binding protein), pleuralins dan sillafins. Selain itu, poliamin berantai ekstrim panjang (LCPAs) dengan distribusi panjang rantai yang sangat spesifik pada tiap spesies ditemukan sebagai bagian penting pada biosilika diatom tersebut. Frustulin dan pleuralins tidak berperan dalam pembentukan silika, namun hanya akan berasosiasi dengan biosilika setelah terdeposit di permukaan sel, sedangkan sillafins dan poliamin berperan dalam polimerisasi silika secara in vitro dari larutan asam silika. Sillafins terikat secara erat dalam biosilika, karena itu, sillafins hanya dapat dilarutkan setelah dinding sel terlarutkan dengan hidrogen fluorida (HF).

Ketika C. fusiforis dilarutkan dalam anhidrous HF, 3 polipeptida yaitu sillafins-2 $(17 \mathrm{kDa})$, sillafins-1B (8 kDa) dan sillafins-1A (4 kDa) berhasil dideteksi bersama dengan materi non protein, poliamin, yang memiliki berat molekul <3 kDa. Dari analisis sekuen protein, sillafins A merupakan campuran 2 peptida yang sangat mirip, yaitu sillafins $-1 \mathrm{~A}_{1},-1 \mathrm{~A}_{2}$ yang memiliki tingkat kemiripan tinggi dengan sillafins-1B. Yang sangat menarik, 3 peptida tersebut berisi 4 (sillafins$1 A_{1},-1 A_{2}$ ) dan 6 (sillafins-1B) lisin yang dimodifikasi. Lisin-lisin hasil modifikasi kovalen yang dikandung dalam sillafins yang merupakan polikation peptida tersebut, adalah lisin pertama, berisi poliamin yang terdiri dari 6-11 ulangan unit N-metil-propilamin. Lisin kedua diidentifikasi sebagai $-\mathrm{N}-\mathrm{N}$-dimetil-lisin. Modifikasi ini akan berpengaruh terhadap aktivitas presipitasi silaffins (Sumper \& Kroger, 2004).

\section{Spons dan Proses Biosilifikasi}

Spons dari perairan laut memiliki struktur silikon dioksida berukuran nano pada spikulanya. Dari 4 klas Spons (Phylum Porifera), 2 klas diantaranya, yaitu klas Demospongiae dan Hexactinellida, memiliki spikula yang mengandung silika. Klas Demospongiae ditandai oleh adanya organisasi seluler dan spikula tipe monoaxonic atau tetraxonic, sedangkan klas Hexactinellida ditandai oleh organisasi sincitial dan spikula tipe hexaradiate. Dua jenis spikula yang diproduksi yaitu megascleres yang menyusun bentuk utama tulang spons, dan microscleres yang sangat bervariasi dalam bentuk dan ukuran dengan fungsi penyokong, yaitu tidak seutama/sepenting megascleres. Bentuk/tipe, ukuran, dan pola spikula dalam tubuh spons selama ini telah digunakan untuk identifikasi spons, karena diatur secara genetik. Tetapi ternyata, kondisi lingkungan juga mempengaruhi keberadaan tipe spikula, sehingga sering ditemukan variasi jumlah, tipe dan ukuran spikula pada jenis spons yang sama (Hooper, 2000)

Pembentukan silika sebagai the building blocks of the skeleton dimulai dengan diekspresikannya enzim silicatein. Ketika Müller dan grupnya meneliti proses pembentukan spikula pada spons Suberites domuncula dengan menggunakan mikroskop, pembentukan spikula disebutkan merupakan proses yang cepat. Spikula dapat tumbuh 5 micron per jam, yang didahului oleh pertumbuhan pada bagian dalam filamen aksial protein silicatein. Spikula ini diproduksi dalam sel yang bernama sclerocytes yang berisi filamen organik aksial, dimana silika secara periodik akan didepositkan sampai bentuk dan ukuran akhir dicapai. Pada beberapa spesies, filamen aksial ditemukan bebas pada mesohyl dan keberadaannya dihubungkan dengan sekresi ekstraseluler spikula (Adamson et al., 2004).

Secara umum, pertumbuhan spikula diasumsikan merupakan proses 2 dimensi yaitu pertambahan panjang dipengaruhi oleh perpanjangan filamen, sedangkan pertambahan lebar ditandai oleh penambahan silika. Pada klas Demospongia, filamen aksial organik yang berfungsi sebagai template (cetakan) diperankan oleh protein yang disebut silicatein. Sampai dengan saat ini terdapat 3 jenis protein silicatein yang berhasil diisolasi dari berbagai spons. Protein-protein ini memiliki kemiripan dengan enzim cathepsin L (Shimizu et al., 1998). Dari perbandingan sekuens antara silicatein dan cathepsin $\mathrm{L}$, ternyata pada cathepsin $L$ terdapat 6 
residu sistein yang dihubungkan dengan jembatan disulfide yang dikonservasi juga pada silicatein sehingga diduga keduanya memiliki struktur tiga dimensi yang serupa. Croce et al. (2004) memodelkan sisi katalitik silicatein seperti pada Gambar 1. Gambaran struktur dasar biosilika pada spons digambarkan oleh peneliti Joanna Aizenberg dari Lucent Technologies dalam Morse, (2006), yang meliputi: struktur dasar dari bulatan-bulatan nano silika (Gambar 2A), yang selanjutnya bulatan-bulatan seperti glas (glassy) ini disusun seputar serat protein dan diatur secara sentris, lapis demi lapis. Setiap lapis silika dipisahkan dari lapisan silika lain oleh selapis tipis protein (Gambar 2B). Struktur ini disebut spikula. Spikula dibungkus secara bersama, lapis demi lapis (Gambar 2C). Perekat berbahan silika menahan satuan ini seperti terlihat pada Gambar 2D.

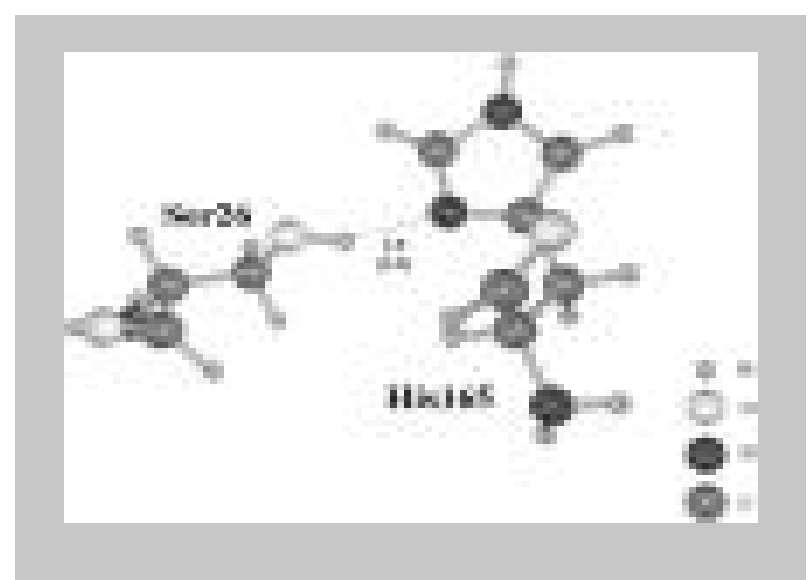

Gambar 1. Posisi relative gusus samping $\mathrm{Ser}^{26}$ dan $\mathrm{His}^{165}$ pada struktur 3 dimensi protein silicatein dari hasil modeling secara teoritis. Yang disebut catalytic triad dari cathepsin yang dibentuk oleh residu Cys ${ }^{26}$, His ${ }^{165}$ dan Asn ${ }^{184}$, pada protein silicatein, 2 dari residu ini yaitu $\mathrm{His}^{165}$ dan Asn ${ }^{184}$ dikonservasi, sedangkan Cys ${ }^{26}$ menjadi $\operatorname{Ser}^{26}$ (Sumber : Croce et al., 2004). matriks inorganik melalui ikatan hidrogen. Kemiripan struktur antara silicatein dengan cathepsin L , lebih lanjut dapat dibuktikan dari prevalensi struktur $\beta$-sheet pada protein spikula yang dianalisis ( $\beta$-sheet adalah struktur sekunder protein, selain $\alpha$-heliks). Dari simulasi interaksi antara sisi aktif silicatein dengan asam orthosilikat atau dalam bentuk anion terdeprotonasi, rotasi gugus samping serin dan histidin melalui ikatan hidrogen dapat membawa 2 unit asam orthosilikat secara bersama, dan pembentukan dimer $(\mathrm{OH})_{3} \mathrm{Si}-\mathrm{O}-\mathrm{Si}(\mathrm{OH})$ dari segi energi sangat dimungkinkan untuk terjadi (Croce et al., 2004)

\section{Biosilika dan Potensi Aplikasinya dalam Industri}

Apa yang telah dilakukan makhluk hidup seperti spons dan diatom dalam memperkuat struktur tubuh mereka melalui proses biosilifikasi, menginspirasi banyak peneliti. Telah diuraikan pada bagian terdahulu bahwa peneliti berhasil mengidentifikasi protein yang bertanggung jawab atas konstruksi pembentukan spikula baik pada tingkat atom maupun molekular. Protein ini selanjutnya berhasil diuji pula kemampuannya untuk membentuk polimer silika secara in vitro dalam kondisi lingkungan yang sangat ringan seperti pada proses biologi biasa. Proses yang digunakan sangat jauh dari proses sintesa silika yang biasa dilakukan, dengan melibatkan suhu sangat tinggi, penggunaan surfaktan yang tidak ramah lingkungan serta boros energi.

Fabrikasi polimer silika berskala nano dibawah kendali protein silicatein dapat diarahkan untuk menghasilkan beberapa jenis bahan semikonduktor, termasuk diantaranya titanium dioksida, yang dapat dilakukan prosesnya pada suhu kamar tanpa adanya bahan kimia berbahaya (caustic). Titanium dioksida sangat efisien dalam mengkonversi cahaya menjadi energi dan ini telah digunakan dalam berbagai
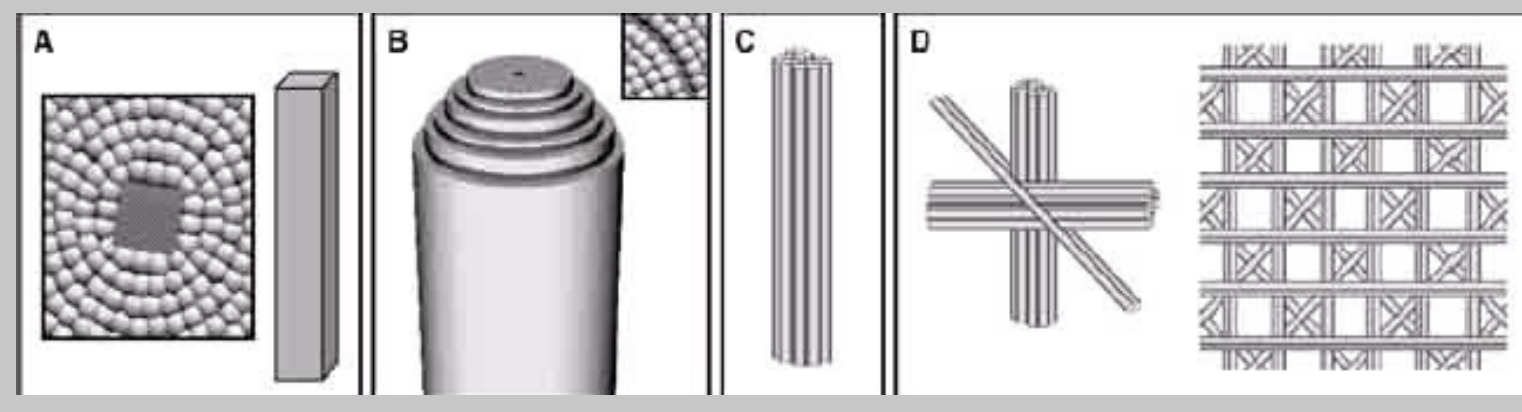

Gambar 2. Strukur dasar biosilika spons (Sumber : Morse, 2006).

Hasil analisis FTIR terhadap peristiwa biosilika ini secara jelas menunjukkan bahwa molekul protein pada filamen aksial berinteraksi dengan gugus $\mathrm{Si}-\mathrm{OH}$ pada keperluan elektronika. Tentu saja apabila proses pembentukan silika secara biologis (biosilifikasi) ini dapat dilakukan pada skala industri, maka akan 
sangat menguntungkan, karena sampai dengan saat ini semikonduktor masih diproduksi dengan menggunakan suhu tinggi dan bahan kimia berbahaya.

Teknologi struktur nano ternyata telah ada dalam kehidupan kita sehari-hari. Ehrmann \& Kuzma (2005) melaporkan dalam bidang industri farmasi, teknologi nano telah banyak digunakan dalam berbagai produk pengantar obat sesuai target (drug delivery system via patch), kulit buatan manusia (man made skin), diabetic insulin biocapsules dan terapi kanker menggunakan targetted radioactive biocapsules. Pada bidang olah raga, berbagai produk bola seperti bola tenis yang lebih awet, bola golf yang melayang lebih lurus, bola bowling yang lebih keras dan raket tenis yang lebih kuat telah dihasilkan melalui teknologi nano dengan performansi yang lebih baik dari teknologi konvensional. Pada industri otomotif, teknologi nano telah digunakan untuk mengisi lubang-lubang yang sangat kecil secara lebih efektif sehingga mobil menjadi lebih mengkilat catnya, dan lain-lain. Peralatan yang berhubungan dengan mata dan optical devices lain, melalui sentuhan teknologi nano, telah menghasilkan peralatan menjadi lebih bersih, lebih kering dan lebih kuat. Celana yang water proof, dan baju atau sepatu yang memberikan rasa dingin pada musim panas dan menghangatkan pada musim dingin, serta kaos kaki yang tidak bau, juga telah dihasilkan melalui teknologi nano. Dalam bidang elektronik, teknologi nano diaplikasikan untuk membuat komputer yang lebih cepat dan lebih powerfull, juga untuk flask drives, kamera digital, cell phone, LCD, LED, flexible electronics, dan lainlain.

Dalam industri pangan, teknologi nano berbahan silika telah digunakan untuk menghasilkan kemasan aktif, penjernih/filter, antikoagulan, dan bahan dasar chip untuk biosensor. Pasar produk ini sangat potensial dengan lonjakan penjualan produk kemasan makanan dan minuman berstruktur nano yang sangat signifikan sejak tahun 2004. Perusahaan pangan raksasa seperti Kraft, Altria dan Unilever, sebagaimana dilaporkan oleh Lux Research, telah menggunakan smart packaging hasil teknologi nano silika karena lebih bersifat inert, tahan terhadap suhu tinggi dan oksigen, mampu mencegah serangan bakteri dan virus serta berpenampilan menarik (El Amin, 2005 dalam Trianawati, 2006).

\section{Riset tentang Protein yang Berperan dalam Biosilika di Indonesia}

Riset mengenai eksplorasi biota laut Indonesia untuk biosilika belum banyak dilakukan. Tiga riset dasar tentang eksplorasi protein yang dapat mengkatalisis polimerisasi silika in vitro serta karakterisasi protein tersebut yang diisolasi dari beberapa spons dan 1 jenis diatom dari Indonesia telah dilakukan. Dari spons asal Binuangen dan P. Nias, telah diperoleh protein dari spikula yang memiliki berat molekul sebesar 21,4 kDa. Selain itu, beberapa protein dengan berat molekul $84 \mathrm{kDa} ; 37 \mathrm{kDa} ; 26,6$ $\mathrm{kDa} ; 18,1 \mathrm{kDa}$ dan $16 \mathrm{kDa}$ juga berhasil diisolasi. Protein tersebut memiliki panjang kurang lebih 0,1 $\mathrm{mm}$ dan berdiameter $10 \mu \mathrm{m}$. Protein yang diisolasi dari Binuangen dapat menginisiasi polimerisasi TEOS (tetraethoxyorthosilicate) sebanyak $15,9 \mu \mathrm{mol}$ setelah 12 jam reaksi pada suhu ruang dan $\mathrm{pH}$ netral (Nurjanah, 2007).

Protein serupa silicatein juga berhasil diisolasi dari spons yang berasal dari $P$. Nias dengan berat molekul $32 \mathrm{kDa} ; 27 \mathrm{kDa}$ dan $23 \mathrm{kDa}$, sedangkan protein yang berperan dalam biosilika pada spons dari Mataram memiliki berat molekul 15,5 kDa dan $18 \mathrm{kDa}$. Dari pengujian protein tersebut terhadap inhibitor spesifik menggunakan Phenyl Methyl Sulfonyl Fluoride (PMSF), protein-protein yang diisolasi ini diduga memiliki salah satu sisi aktif berupa serin. Hasil isolasi protein dari kelima spons menunjukkan bahwa kemampuan melakukan polimerisasi tertinggi adalah sebesar $144 \mu \mathrm{mol} / \mathrm{mL}$ dengan lama reaksi 12 jam. Dari studi kinetika, protein tersebut mengikuti kinetika Michaelis-Menten dengan nilai Km sebesar $47,59 \mu \mathrm{mol} / \mathrm{mL}$ dan Vmax sebesar $4,7 \mu \mathrm{mol} / \mathrm{jam}$ (Trianawati, 2007).

Protein seperti sillafins dari dinding sel diatom Chaetoceros gracilis telah diisolasi dan diuji kemampuan melakukan polimerisasi silika dengan substrat TEOS. Dari pengujian tersebut diperoleh yield $0,34 \%$ atau $64 \mu \mathrm{g} / \mathrm{g}$ sampel dan didapatkan 4 pita protein dalam SDS-PAGE, masing-masing memiliki berat molekul 44,65 kDa; 42,18 kDa; 23,88 kDa dan 12,07 kDa. Protein tersebut mampu melakukan polimerisasi TEOS sebesar $239,74 \mu \mathrm{mol} / \mathrm{mL}$, TEOS monomer dalam waktu reaksi 24 jam (Manurung et al., 2007).

\section{PENUTUP}

Peranan protein dalam proses biosilifikasi menjadi semakin penting seiring dengan potensi aplikasi protein tersebut dalam memproduksi berbagai produk berbahan baku silika yang bersifat ramah lingkungan. Protein tersebut bekerja seperti enzim dan menjadi cetakan, dengan pola/tipe yang spesifik, tergantung dari jenis atau spesies biotanya, yaitu diatom dan spons tersebut (bersifat genetik). Temuan tersebut mengindikasikan bahwa, eksplorasi terhadap protein dari biota laut menjadi sangat penting untuk mendapat protein dengan kemampuan biosilifikasi skala nano dengan pola unik atau pola tertentu seperti yang kita kehendaki untuk aplikasi industri nantinya. 
Hasil riset tentang biosilifikasi pada spons dan diatom di Indonesia memang masih bersifat sangat awal dan jauh untuk aplikasi. Hasil ini dapat dijadikan pancingan riset selanjutnya, mengingat potensi aplikasi biosilika dalam memenuhi kehidupan seharihari cukup besar. Kekayaan biota laut Indonesia dengan megabiodiversitas hayati sangat tinggi, sangat berpotensi dalam menghasilkan berbagai protein unik yang berperan dalam proses pembentukan biosilika skala nano.

\section{DAFTAR PUSTAKA}

Adamson, D.H., Dabbs, D.M., Morse, D.E. and Aksay, I.A. 2004. Non-peptide, silicatein á inspired silica condensation catalyst. Polymeric Materials: Science \& Engineering, 90, 239

Bradburry, J. 2004. Nature's nanotechnologist : Unveiling the secrets of diatoms. PLos Biol. 2004. October, 2 (10) : 306

Croce, G., Frache, A., Milanesio, M., Marchese, L., Causà, M., Viterbo, D., Barbaglia, A., Bolis, V., Bavestrello, G., Cerrano, C., Benatti, U., Pozzolini, M., Giovine, M. and Amenitsch, H. 2004. Structural characterization of siliceous spicules from marine sponges. Biophys. J. 86 (1) : 526-534

Ehrmann, B. and Kuzma, T. 2005. Real World Application of Nanotechnology. Center for Nanotechnology Education \& Technology. Pensylvania State University. Latest úpdate on June 17, 2005

Hooper, J.N.A. 2000. Sponguide : Guide to sponge collection and identification (version August 2000). http://www.qmuseum.qld.gov.au
Manurung, A.I., Suhartono, M.T., Syah, D. and Pratiwi, A.R. 2007. Catalyzing formation of silica structure isolated from Indonesian marine diatom Chaetoceros gracillis. Proceeding of International Seminar and Workshop Marine Biodiversity and Their Potential for Developing Bio-Pharmaceutical Industry in Indonesia.

Morse, D.E. 2006. Marine Bio-nanotechnology : High Performance Materials from Sponge Silicatein. California SeaGrant College Program. Research profiles

Nurjanah, S., Welson, Suhartono, M.T. and Chasanah, E. 2007. Preliminary analysis of silicatein like protein from the Indonesian sponge catalyzing silica polymerization in vitro. Proceeding of International Seminar and Workshop Marine Biodiversity and Their Potential for Developing Bio-Pharmaceutical Industry in Indonesia

Parkinson, J. and Gordon, R. 1999. Beyond micromachining : The potential of diatoms. TIBTECH, $17: 190-196$

Shimizu, K., Cha, J., Stucky, G.D. and Morse, D.E. 1998. Silicatein $\alpha$ : Cathepsin L-like protein in sponge biosilica. Proc Natl Acad Sci, U S A. , May 26; 95(11): 6234-6238.

Sumper, M. and Kroger N. 2004. Silica formation in diatoms : The function of long chain polyamines and silaffins. J. Mater. Chem., 14 : 2059-2065

Trianawati, L. 2007. Karakterisasi Protein Serupa Silicatein dari Sponge Asal Perairan Nias dan Lombok. Thesis S2, Sekolah Pasca Sarjana IPB, Bogor. 